\title{
FILM NOIR'S SORCERER OF LIGHT: JOHN ALTON
}

\author{
John Bailey
}

At the end of his preface to Painting with Light, cinematographer John Alton says he wrote the book not as a technical work but from a "desire to share the fruits of his experience with kindred souls who also delight in capturing bits of light at rest on things of beauty."

The phrase "bits of light" seems apt for the lighting technique of a man who could claim the crown of "Prince of Darkness" decades before Gordon Willis. But "light at rest on things of beauty" is an unlikely image for the violent, eruptive world of deceit, betrayal, and murder that lies at the heart of Alton's best-known movies, a world so amoral and ugly that its denizens never aspire to anything more than B-movie status on the bottom half of a 1940s double bill-and who'd never presume to roam the august corridors of the Academy of Motion Picture Arts and Sciences' Oscar temple. It's fittingly ironic that the single nod which that Hollywood establishment gave Alton during his active career was not for his signature lighting and compositions in the noir films of Anthony Mann and Joseph Lewis but for a single dance sequence in the beloved Technicolor musical $A n$ American in Paris. Even with his Oscar in hand, Alton was not much embraced by his peers or at the American Society of Cinematographers. To many of them he was a nonconformist, an outsider rebel in a community noted for its close bonds and nepotism. Alton was earlier a member of the society, but after his premature retirement, his name was barely mentioned in the ASC Clubhouse, which in the early 1980s was still a private enclave, a gentleman's club replete with the flow of hard liquor and dense with lingering cigar smoke around the bar and pool table. The "arty" Alton was an unlikely fit. I knew this venue well; that is how it was when I became a member in 1985. The old lion and society president Stanley Cortez, whom we younger upstarts called the Baron for his oftimperious tone, challenged most visitors who dared cross the sacred threshold of the Orange Drive Clubhouse. It was a world apart from the inviting and expansive meeting place for members, industry experts, and film students that it is today.

Todd McCarthy's biographical essay (see p. xix) is a much-needed and insightful presentation of the life and work of a man who weaved in and out of the Hollywood mainstream and even more quixotically among his cinematographer peers. Alton came to Hollywood in 1924 and soon found a job at the MGM laboratory. He flirted with the studio system for a few years, then left for a decade of work and travel-at first in Europe, then in the cinematic backwaters of Latin America during most of the 1930s. He returned to a skittish embrace of Hollywood in 1939, served in the army as a lab expert during the war, and dug deeply into the quickie B noir films of post-WWII. He achieved an unlikely aesthetic apotheosis in the riot of color and dance of 195l's musical An American in Paris that is equal to Jack Cardiff's in The Red 
Shoes. A few years later he got rustled into a series of low-budget Allan Dwan westerns with second-tier actors like John Payne and Ronald Reagan, undistinguished quickies that seemed the antithesis of his brooding noir work. Rescued by Richard Brooks, his favorite director (they made five movies together, starting with 1953's Battle Circus), he left the 1950s in a blaze of glory with Brooks's Elmer Gantry, a superheated vehicle for the outsize persona of Burt Lancaster. Alton's looming shadows and deep focus, first used in his 1940s noir period, finally found synthesis with a studio star vehicle in this adaptation of the Sinclair Lewis novel. But Gantry was to be his swan song on the big screen. He virtually disappeared from Hollywood filmmaking, even though he continued to live in the town with his wife, Rozalia, in an apartment on North Sweetzer. Alton emerged briefly in 1965, to photograph the pilot for the TV series Mission: Impossible for writer Bruce Geller and director Bernard Kowalski. Then he disappeared-again.

McCarthy's moving footnote to Alton's career is his description of the cinematographer's surprise appearance at the premiere of the American Film Institute and ASC documentary on the history of cinematography, Visions of Light, which McCarthy codirected, in February of 1993 at West Los Angeles' art house cinema the NuArt. I was there, along with more than a dozen other cinematographers featured in the film. Alton received more than the ovation described by McCarthy. The buzz among his peers and us younger acolytes didn't stop for days. I was especially gratified because McCarthy and I had focused on the noir period in the documentary, which featured a clip from the foggedout airport scene that ends The Big Combo, a late entry, like Touch of Evil, in the sweepstakes for last black-and-white noir masterpiece.

There has been much speculation about why Alton decided to drop off the cinematic radar. When John Frankenheimer fired him shortly after replacing director Charles Crichton on
Birdman of Alcatraz, it signaled more than a simple mano a mano heave-ho. Frankenheimer was one of the new generation of "auteurs" who evolved out of directing 1950s live TV and saw themselves as much creators of the image as did cinematographers - in a way that Dwan, Anthony Mann, Joseph Lewis, Bernard Vorhaus, and Robert Florey did not. Also, Alton had worked with many lesser-known directors, such as Joseph Kane, George Blair, and Albert S. Rogell, men who certainly left the image making to the wiry, pencil-mustached man who seemed to be everywhere on the set at once.

We cinematographers are noted for long careers-Karl Struss, James Wong Howe, Freddie Francis, Jack Cardiff, Freddie Young, Richard Kline, and Bill Butler come to mind. There was no apparent reason to believe John Alton would stop when he did. Except for the anomalous TV pilot, Alton had pulled the plug on cinematographing at fifty-nine, an act he later called his "only mistake." But the fact is, he didn't really pull the plug, at least not in his mind.

During the last years of his life Alton insisted he had retired in order to travel and paint-at least this is what he told McCarthy and other critics and scholars who interviewed him. But I believe he harbored a bittersweet ambivalence at having stopped so early and was wounded at having been replaced on his final two assignments.

While researching for this essay at the AMPAS Herrick Library (mainly in the ASC papers), I found a letter that Alton had written to director George Cukor on November 15, 1964, several years after his retirement. He wrote to praise Cukor's My Fair Lady as "one of the greatest films of all time ... It awakened in me an ambition: TO PHOTOGRAPH A FILM FOR YOU." The caps are Alton's, and the subtext seems to me to be that the director would be the greater benefactor in such a collaboration. Modesty was not known to be one of Alton's traits. He continued, "Although I have been absent from Hollywood, the time thus spent has not been in vain." Alton explains to Cukor his ongoing study of color, 
which many of his colleagues felt had run amok in Brooks's The Brothers Karamazov. Although there had been hints of expressionistic color in My Fair Lady, it is difficult to imagine that the aesthetic bent of the always-genteel Cukor could mesh with that of the showy Alton, whose bold color slatherings, in the style of Matisse, van Gogh, and Toulouse-Lautrec, brought howls of protest as far back as An American in Paris. In closing, Alton suggested to Cukor in heraldic caps, "I WOULD GREATLY APPRECIATE AN OPPORTUNITY TO TAKE PART IN SOME COMPETITIVE TESTING FOR YOUR NEXT PRODUCTION." I found no reply from Cukor among the director's papers.

But even two years before his retirement, ostensibly when he was burning out, Alton wrote to George Stevens, on January 16, 1958. Stevens, like Cukor, was an A-list director of broadly humanistic dramas. Early in his career he had been a cinematographer, with dozens of photography credits dating back to 1923, including a number of Laurel and Hardy two-reelers for Hal Roach. Alton wrote Stevens the year before the release of his bio-drama The Diary of Anne Frank, photographed by William C. Mellor (Mellor earned the Oscar for his black-and-white photography). Alton began, "What a powerful instrument the motion picture camera can become in your hands. So I have decided that before I retire, I shall have to photograph one of your pictures." As suggested earlier, modesty was not a mantle that Alton wore comfortably. $\mathrm{He}$ went on to describe his on-and-off, love-hate affair with MGM, citing his "ABSOLUTE NEW APPROACH" to color in The Brothers Karam$a z o v$. Alton concludes, "Should you ever be in need of a man of my caliber, I shall be glad to hear from you." Such a self-serving, even unctuous, sign-off would seem to bode no response. But the affable Stevens did reply, on February 6. "Nothing would make me happier than an opportunity for this kind of an association in the future," he wrote simply. Stevens would direct only two more films. On The Greatest Story
Ever Told he used Mellor again, along with Loyal Griggs, and on his final film he chose the great cinematographer of the early Nouvelle Vague films Henri Decaë. A Stevens-Alton linking remains one of those "what if" questions of film history.

Another conundrum surrounding Alton's career is his erratic relationship with the American Society of Cinematographers. The ASC was chartered in 1919; its founding members were fewer than two dozen youngsters who were to become the industry establishment. Some of the earliest members had careers that reached even into the American New Wave of the late 1960s.

It is likely that Alton decided to apply for membership in the ASC when he briefly returned to Hollywood in 1937 to photograph $L a$ Vida Bohemia. His application, dated December 1, 1937, lists him as "Jack" Alton and gives an address of $1268 \mathrm{~N}$. Flores Street in West Hollywood. His sponsors were the members John C. Stumar, a fellow Hungarian, and Stanley Cortez. The latter, still a tyro cinematographer, was years away from his first great credit, on Orson Welles's The Magnificent Ambersons. Cortez would emerge again near the end of Alton's life. In his ASC application, Alton mentions that he is "at present working on a textbook of photography entitled 'Photo Vibrations.' " Throughout his career, Alton cited his ongoing writing, which he used to distinguish himself from his peers. The allusion here is perhaps to an early draft of what would be published in 1949 as Painting with Light.

The ASC accepted Alton barely a week after he submitted his application, on December 10, 1937. However, he was soon back in Latin America. One reason for his return to Buenos Aires can be discerned in a letter he wrote to ASC executive board manager Fred L. Kley on June 22, 1938: "For the time being, it would be foolish [to] come back to Hollywood, and try to penetrate the Chinese wall of camera departments." Clearly, this is an allusion to his nemesis John Arnold, with whom he had a long-running 
feud. Arnold was the powerful head of the MGM camera department from 1931 to 1956; he was also president of the ASC in 1931-37 and again in 1939-41. Though he had not photographed movies since 1929, Arnold was a force every cinematographer had to reckon with.

Nonetheless, Alton's second return to Hollywood was announced in a puff piece in the November 1939 issue of American Cinematographer. It reads as if a publicist had written a résumé of Alton's decade-long wanderings in Europe and Latin America as a herald of his anticipated American career. Despite this article, Alton had to make do with photographing a string of small movies, starting with the 1940 The Courageous Dr. Christian, the first of eight films he made with director Bernard Vorhaus. Vorhaus and his wife were leftists and had supported the Loyalist cause in the Spanish Civil War. In 1951, Vorhaus became a victim of the Hollywood blacklist when director Edward Dmytryk gave his name to the House Un-American Activities Committee. Vorhaus and Alton's last film, 1948's The Amazing Mr. X, featured beautiful exterior day-for-night footage from a beach seamlessly intercut with close-ups shot under studio lighting and with back projection. The film is an anomalous straight drama smack in the middle of Alton's noir period. Little seen today, it remains one of his most accomplished credits, as is the even more anomalous The Black Book, a film directed by Anthony Mann in 1949. Also known as The Reign of Terror, it tracks the rise and fall of Robespierre during the late phase of the French Revolution. Going almost perversely against the grain of typical historical dramas, Alton and Mann engulf the film in every tic and trope of the style they crafted in films noirs such as T-Men and Raw Deal. Instead of car chases and shootouts, there are careening horse-drawn carriages and sword fights, and through them all the deep shadows and penetrating light shafts that constitute the genre's grammar. In many ways The Black Book is the purest exemplar of Alton's noir style, be- cause its eighteenth-century setting is so alien to noir's universe.

Alton was on the precipice of a major studio career when he took a left-hand turn that even today is a head shaker. It is anybody's guess why he wrote to Fred Jackman at the ASC requesting withdrawal from the organization. In a letter dated January 1, 1944, Alton writes, "Due to the fact that in the future I shall have no time to make use of the ASC Clubhouse, the only advantage the Club has to offer, allow me to express my desire to withdraw from the membership of your organization (ASC) to take effect Jan. 1, 1944." This must have seemed a broadside to Cortez, one of his sponsors. Alton had been a member less than six years. Jackman replied a few days later, "I personally think you are not using good judgment in expressing your desire to withdraw from membership in this organization." Apparently, this had no effect on Alton, because Leonard Smith, the ASC president, notified him on January 11 that the Board of Governors had approved his resignation. Alton must have eventually realized he was committing career suicide within the tightly knit cinematographer community. More than a year later, he requested readmission, with support from cinematographer Leon Shamroy. Alton was instructed to pay current dues. He was back in the fold.

But this was not the end of Alton's checkered ASC history. Less than a decade later, several years after winning the Oscar for the ballet sequence in An American in Paris, Alton again sent a letter to the ASC board: "In the future I shall be mostly traveling and writing. I shall have no time for social activities here whatsoever. Therefore, please accept my resignation from your organization as of March 30, 1954." The loaded phrase "your organization," not "our organization," is precisely the one he had used in his January 1944 letter of resignation to Jackman. Clearly, Alton did not feel he was one of the club. Whether his alienation was that of the refined artist amid a covey of yahoos or the 
result of peer controversy over his Oscar win, frustration at being caught in a string of $\mathrm{B}$ titles, or even delayed outrage about the blacklisting of his friend Vorhaus is speculative. Richard Kline, who was the camera operator on several of Alton's last movies, portrays him as a gentleman who never spoke harshly of anyone. What is indisputable, however, is that on the next six features, for director Allan Dwan, after his ASC withdrawal, Alton's credit reads "Director of Photography, John Alton." There is no ASC attribution-nor is there for his credit on the seminal The Big Combo, nor on any of his subsequent titles.

Resentment toward Alton may have gone as far back as the 1949 publication of his book, which was the first detailed how-to published by a major Hollywood cinematographer. It has remained a staple since publication, even though the equipment Alton pictures is in many cases barely recognizable to the current brood of cinematographers, hatched by Kino-Flo fluorescents and LEDs rather than the warming rays of tungsten "Babys."

I found an interview with Alton from an unidentified trade publication, byline Virginia MacPherson. It reads as a post-Painting with Light screed and may go some way to explain why his fellow cinematographers may have had it in for Alton. He tells the writer, "I don't see [use?] any top lighting. Other cameramen have heavy arcs and lights all around the top of a soundstage. I put my lights on the floor. This way the actors come out looking like people not masks." Alton was referring to the industrywide practice of ringing the set with scaffolds hung from the stage "permanents," the large steel beams bridging the stage roof. Heavy chains supported these railed wooden walkways, where a crew of grips and electricians spent their workday. The "juicers" focused the lights at the command of the lighting gaffer, who worked from the floor. Grips modeled the lights with a bevy of cutters and flags hung from the safety rails. The shadows sank down low on the set walls and were easy to cut just above the actors' heads. You can see this light and shadow scheme in almost any studio film of the 1930s50 s. The scaffolds were commonly called greenbeds because of the dominant color of the wood floor grid. Greenbeds are still found on standing sets of episodic TV shows. Contrary to what Alton insisted, these hanging scaffolds were very fast to light from. When placed low on the floor, movie lights are tricky to hide behind desks and furniture. But they do cast dramatic shadows from the actors, a signature of noir style. The hard-light sources of black-and-white noir deploy a hot keylight against an ambiguous dark surround, with a bright white accent in the background, creating a sense of deep space. Along with wide-angle lenses and high F-stops, this makes the contrived depths of early 1950s 3-D flicks seem little more than a grace note. Alton and Nick Musaraca represented the cutting edge of noir cinematography. While many A-list cinematographers may have wanted to flirt with noir lighting, it was anathema to the major studios' house styles, which required contract cinematographers to always make the stars look beautiful and desirable.

At the time of Painting with Light's publication, there was still a lot of mumbo jumbo about cinematography. Every cameraman had his little box of secret filters and nets and his personal way of exposing negative. Even when I began as an assistant in the late $1960 \mathrm{~s}$, there were plenty of cinematographers disinclined to mentor students, even their own assistants. Some cinematographers would whisper the lens setting to the camera assistant as though this were the key ingredient in a secret sauce. I worked with only a few of these veterans, as they were far too insulated inside the union hierarchy for a tyro like me to approach. In an era of tie-dye, they still wore jackets and ties on the set. Alton's tell-all book must have seemed to them a violation of the trade's cabbala-like secrets.

With the exception of The Big Combo and Slightly Scarlet, much of Alton's noir style ran 
aground in the mid-1950s. There are only hints of it in the routine westerns he did with Dwan in 1954 and 1955 . There is a scene where it makes a full-blown appearance, however, in The Cattle Queen of Montana, when Barbara Stanwyck visits the tepee of nearby Indians. The campfire is barely readable as a light source, but a low, off-screen keylight casts high, hard shadows on the walls of the tepee, prefiguring the office of syndicate crime boss Solly Caspar in Slightly Scarlet, Alton's last film with Dwan. Shot like their westerns in a bogus wide-screen format called SuperScope, Slightly Scarlet promised to be another B-movie programmer, but it is so resolutely dark in character and tone, so self-assured in its embrace of classic noir tropes, that it almost creates its own genre. It's a small step from there to Alton's color chaos in The Brothers Karamazov when Dmitri becomes unhinged after he tries to kill the servant Grigori.

Things began to change in Hollywood cinematography as color became common in the late 1950s and early 1960s. It's fascinating to see the ways in which many of the great veteran hard-light black-and-white cameramen faced their first forays into color. Many late 1950s studio color films were still lit in classic black-andwhite style. To today's eyes, they seem overwrought, artificial. Many cinematographers were yet to take a lesson from their European colleagues, who, though they moved to color later than Hollywood cinematographers, had an instinctive sense that color itself created depth and separation. Almost from the beginning of their color work, the Europeans Raoul Coutard, Sven Nykvist, Néstor Almendros, and Giuseppe Rotunno embraced a softer style of light, one that influenced the emerging American New Wave of Conrad Hall, Jordan Cronenweth, Laszlo Kovacs, Vilmos Zsigmond, Owen Roizman, and John Alonzo. One of the holdouts was the great Phil Lathrop, with his work in John Boorman's 1967 film Point Blank. It reeks of classic Hollywood hard-light noir, but its daring editing and soundscape cover all the New Wave bases - and even created new ones. Alton, typically, seemed to make the transition on his own terms.

It is more than curious that although Alton published Painting with Light at the acme of his noir period, he almost pointedly avoids any detailed analysis of that style. His nod to noir is chapter 3, "Mystery Lighting," barely a dozen pages of text. The bulk of his book concerns those "bits of light at rest on things of beauty." The text is a veritable stew of the secrets of Hollywood studio lighting techniques of its day, seasoned with Alton's idiosyncratic notes. The fourteen chapters range from an introduction of cameras, lights, and grip equipment to descriptions of some of Alton's personal "trick rigs" and sections on the laboratory and how to set up a portrait studio. He presents ideas for improved theater projection and in a concluding chapter uses the camera as a metaphor for the human sensory system and brain. It's a window onto Alton's philosophic musings and calls to my mind at least the whimsical image of Dziga Vertov's stop-motion kinetic camera and tripod. But, as the title promises, Alton concentrates the major chapters on different moods of classical lighting, extending even to light control for day exterior scenes.

A key section is chapter 5, "The Hollywood Close-Up." Here Alton discusses his eight-light system and the three-circle clock as a guide to effective portrait lighting. Figures 181 and 182 show his "light stick," a low-wattage bulb attached to a shaft. Pictured in front of actress Joan Bennett, with whom he first worked on Hollow Triumph, it is a shorthand tool to help determine the most appropriate angle to set his keylight: a sorcerer's light wand. Alton returns to his study of flattering portrait lighting in chapter 12, "Day and Night, Ladies, Watch Your Light." A subheading is "Ladies' Light Is Men's Delight." Even in the darkest depths of his noir sets, Alton found ways to create luminous, luscious close-ups of his leading ladies.

Since the early days, the intimate relationship of cinematographers and actresses has been a hallmark of American films. Mary Pickford had 
a long-standing relationship with Charles Rosher, who was succeeded by Karl Struss; James Wong Howe solved the problem of Mary Miles Minter's pale eyes; Lucien Ballard created the "Obie" light for his accident-scarred wife, Merle Oberon. Although Alton is deemed king of the noir style, Painting with Light reveals the beating heart of a portrait photographer. It's hard to imagine him praising another photographer, but the spirits of George Hurrell, Donald Ritchie, and even Herb Ritts must hover around him in a cinema empyrean, the locus of light.

Even though the illustrated cameras, lights, and grip equipment that Alton employed are obsolete, the underlying principles he presents are as useful today as they were in 1949. Hard light has all but disappeared from contemporary movies and with it many of the kickers, backlights, and hair lights Alton discusses. Today's soft light and bounce light from large reflective panels demand much larger light control cutters than Alton used, but his guidelines are still applicable. He also describes exotic devices, such as the "receding track" of figures 10-12 and the Destycrane of figure 14 (an overhead rail system that promised the freedom realized with today's Technocrane). It's difficult to determine whether these and similar proposals were working devices now unknown to us or draft ideas gleaned from his musings.

One of the most fascinating sections of the book is chapter 9, titled "Visual Music." Here Alton discusses the classic gray-scale tonality of pure white to total black in terms of music. The metaphor may seem stretched, but it is in effect a lucid explanation of his theory of noir lighting. Figures 226 and 227 explain his rationale for placing bright light in the deepest part of the set and black (such as a silhouette) in the foreground. He writes, "In between the two there is space, a musical feeling of depth. Just as in music, a melody of two is monotonous to the ear, so in photography, two intensities of light are wearisome to look at."

After his years of self-imposed exile from Hollywood, Alton's coming out at the premiere of Visions of Light signaled a late incandescence in his life. His subsequent public appearances were as a genial nonagenarian sporting a dark beret, still-generous locks spilling onto his neck, framed by a bow tie.

The year before he died, Alton was invited to the ASC Clubhouse to be honored during a monthly members' dinner. $\mathrm{He}$ and his ASC sponsor from December 1937, Stanley Cortez, sat at separate tables in the L-shaped room. They were eyeing each other across the way, but neither made a move toward the other. Clearly, there was some unresolved history between the two, which those of us in the room could only surmise. Did it go back to Alton's two withdrawals from the society or was it personal? None of us were aware that Cortez had been his original sponsor, and Cortez remained unusually mum. Stanley was quick to challenge anyone who disagreed with him at board meetings, but many of us knew that his sentinel-like demeanor at the ASC portal was partly a front; somewhere inside that glowering visage resided a more mellow soul. Whatever old resentments might present a chasm between these two artists, several of us, including Woody Omens, felt it was time for rapprochement. We led Stanley over to Alton's table. There was a slight hesitancy, but Stanley made the first gracious move, and they embraced each other. I was aware, as never before in my professional life, that here was a direct connection to a golden age of American cinematography. I think it was Omens who took a photograph of Alton, Cortez, and me standing next to the fireplace, above which is the ASC insignia. Alton is in a dark suit, his bow tie askew to the left; Cortez, ever dapper, wears a white jacket with an ascot. His right arm rests on Alton's left shoulder. I stand between the two Lions in Winter like the cat that ate the canary, an unlikely acolyte in his early fifties, not yet with a trace of gray hair.

To see John Alton honored in the ASC Clubhouse that he had decades before abandoned was to bear witness to an unlikely fact. In an industry rife with petty and large rivalries and 
with career-long competitions gilt over by the gloss of the annual Oscarfest, cinematographers have portrayed themselves as true colleagues, sharing aesthetic and technical knowledge in the intimate space of the Clubhouse. There is much truth to this representation. Indeed, the ASC continues to reach out to emerging filmmakers through its many committees and pro- grams. Alton's appearance that evening was balm on a too-long-festering wound. Were he alive today, there is no doubt he would be at the Clubhouse, sharing his knowledge and war stories with students. But we do have Painting with Light, a window onto the world of image creation from a golden age, an age that still resonates in our work. 